\title{
PKD1 Gene
}

National Cancer Institute

\section{Source}

National Cancer Institute. PKD1 Gene. NCI Thesaurus. Code C75894.

This gene plays a role in kidney development. 